\section{Taxonomic Relevance of Calcium Oxalate Cuticular Deposits in Dracaena Vand. ex L.}

\author{
Svoboda V. Pennisi ${ }^{1}$ \\ Department of Horticulture, University of Georgia, Coastal Plains Experiment \\ Station, Tifton, GA 31793
}

\section{Dennis B. McConnell ${ }^{2}$ \\ Department of Environmental Horticulture, University of Florida, Gainesville, FL 32611-0670}

Additional index words. crystalliferous cuticle, cuticular periplasmic crystals, Dracaenaceae, Agavaceae, Cordyline, Sansevieria

\begin{abstract}
Detection of cuticular crystals in the 14 species of Dracaena examined indicated that they are probably ubiquitous throughout the genus and may permit rapid separation of dracaenas from plants with similar leaves such as the cordylines (Cordyline sp.). Dracaena species of the dragon tree group deposit the greatest quantity of uniformly small cuticular crystals. However, the distinction between individual species within this grouping, based solely on crystal numbers and size, is not sufficient for taxonomic separation. All other species of Dracaena studied did display species-specific quantities and sizes of cuticular crystals. This, in combination with characteristics of the leaf epidermis, could serve as part of a taxonomic key to the genus.
\end{abstract}

The monocotyledonous genus Dracaena Vand. ex L. consists of $\approx 60$ species (Hutchinson, 1986), and all members except one (D. americana J.D. Sm.) are indigenous to tropical regions of Africa and Asia. Cultivated species of Dracaena are popular houseplants and widely used in interior landscapes. Also, Dracaena is the most economically important genus of foliage plants grown in Florida (McConnell et al., 1989). They are usually sold as small juvenile plants $(20 \mathrm{~cm}$ to $2 \mathrm{~m}$ in height), but in their native habitats, some species reach considerable heights (6 to $20 \mathrm{~m}$ ). Because the juvenile stage is commonly used, identification is based primarily on leaf morphology. Leaves of Dracaena species may be pliable or stiff and their shape varies from linear to sword-shaped to lanceolate, with clasping flaring leaf bases or distinct petioles.

Received for publication 18 May 2000. Accepted for publication 13 Dec. 2000. Florida Agricultural Experimental Station journal series no. R-07510. Based on part of a dissertation accepted in partial fulfillment of the requirements for a $\mathrm{PhD}$ degree at the Univ. of Florida. Mention of a trademark, proprietary product, or vendor does not constitute a guarantee or warranty of the product by the U.S. Dept. of Agriculture and does not imply its approval to the exclusion of other products or vendors that may also be suitable. The authors are grateful to Aguedo Marrero and Rafael Almeida for herbarium samples and to Bijan Dehgan and Jake Henny for review of the manuscript and instructive criticism. The cost of publishing this paper was defrayed in part by the payment of page charges. Under postal regulations, this paper therefore must be hereby marked advertisement solely to indicate this fact.

${ }^{1}$ Assistant Professor.

${ }^{2}$ Professor. To whom requests for reprints should be addressed. E-mail address: dmcconnell@mail. ifas.ufl.edu
Most of the cultivars commercially grown have variegated leaves. Within the genus, leaves are variable in length $(\approx 40 \mathrm{~cm}$ long $)$ and are narrow $(<1.5 \mathrm{~cm})$ to broad $(>5 \mathrm{~cm})$.

Hutchinson (1959) assigned Dracaena to Agavaceae Endl., but Takhtajan (1980) placed it in a separate family, Dracaenaceae Salisb., related to Asparagaceae Juss. (or Liliaceae Juss. subfam. Asparagoideae Kostel). Recent analysis of internal transcribed spacer (ITS) rDNA sequence of 40 taxa in Agavaceae justified this placement in Dracaenaceae (Bogler and Simpson, 1996). Sansevieria Thunb. forms a monophyletic group with Dracaena and the genera are very closely related. The vegetative and floral anatomy of some species of Cordyline Comm. ex R. Br. closely resemble those of some members of Dracaena (Bogler and Simpson, 1996). This similarity is often a source of confusion in field identification, and retail nurseries often sell species of Cordyline as red dracaenas. However, according to Bogler and Simpson (1996), Cordyline has a clearly divergent ITS sequence, setting it apart from members of Dracaenaceae.

Extracellular epidermal crystals in dracaenas were documented by Kohl (1889), who described relatively large rhombohedral crystals associated with epidermal cells of Dracaena fragrans (L.) Ker-Gawl. Fink (1991) reported that $D$. cincta Bak. (syn. D. marginata Lam.) had small crystals embedded within the cuticular layer above the striated epidermal cell wall. Pennisi et al. (2001) reported small $(<1$ to $6 \mu \mathrm{m})$ crystals beneath the cuticle of Dracaena sanderiana hort. Sander ex M.T.Mast. These consisted of calcium oxalate monohydrate (COM) and were formed in close proximity to the epidermal cell cytoplasm. Members of Cordyline do not possess cuticu- lar crystals, but members of Sansevieria exhibit minute $(<1 \mathrm{~mm})$ crystals in the cuticle (Pennisi, 1999). The objectives of this study were to investigate the occurrence of crystalliferous cuticle in selected Dracaena species in order to determine its taxonomic relevance in providing additional characters for segregation of cultivated Dracaena species.

\section{Materials and Methods}

Plant materials. The Dracaena species used in this study were obtained from two general sources. The cultivated group included those species commonly grown as foliage plants in the United States. The second group was the dragon tree group from Spain and Gran Canaria, although D. draco (L.) L. is commonly grown in the United States. The following species were compared: Dracaena arborea (Willd.)Link; D. cincta;D. deremensis Engl.; D. draco; D. fragrans; Dracaena $\times$ massefiana hort. (a hybrid between $D$. fragrans 'Massangeana' and D. surculosa); D. reflexa (Descne.) Lam.; D. sanderiana; $D$. surculosa Lindl.; D. thalioides hort. Makoy ex E. Morr.; Cordyline australis (Forst.) End.; C. terminalis (L.) Kunth; Sansevieria cylindrica Bojer.; and S. trifasciata hort. ex Prain. All Cordyline, Dracaena, and Sansevieria species were grown in the conservatory of the Environmental Horticulture Dept. at Gainesville except $D$. arborea, which was grown at a local nursery. In addition, herbarium specimen of four species from the Jardin Botanico Canaria "Viera y Claijo"(JBC) in Spain were examined: D. cinnabari Balf.; D. ellenbeckiana Engl.; D. ombet Kots. \& Peyr.; and D. tamaranae Marrero et al. The first three species had been grown in the JBC, while the last species originated from Gran Canaria. Authorities for these herbarium specimens are as listed in Marrero et al. (1998). All specimens from Spain, along with D. draco, are considered to be in the dragon tree group, an arborescent taxa of Dracaena found in East and West Africa (Marrero et al., 1998).

Methods. Epidermal peels were obtained from leaves from three plants of each species using the following procedure. Fresh mature leaf material $(1 \mathrm{~g})$ was cut into $10 \times 10-\mathrm{mm}$ pieces and placed for $48 \mathrm{~h}$ in a maceration solution $(10 \mathrm{~mL})$ containing cellulase $(1.0 \%$ $\mathrm{w} / \mathrm{v})$, hemicellulase $(1.0 \% \mathrm{w} / \mathrm{v})$, and pectinase $(0.1 \% \mathrm{w} / \mathrm{v})$ (Protoplast Isolation Enzyme Solution I; Sigma-Aldrich Co., St. Louis). The epidermal peels from herbarium specimens (two leaves from each species) were obtained by soaking the leaves for $3 \mathrm{~h}$ in boiling water prior to enzymatic digestion. After maceration, adaxial and abaxial epidermal peels were obtained by gently pulling the epidermis away from the underlying mesophyll. The peels were rinsed in ethanol, placed on glass slides and examined with a Nikon Optiphot-Pol research microscope (Nikon Nippon Kogaku K.K., Tokyo) equipped with polarizing optics. Detailed cellular measurements were made with an ocular micrometer and crystal counts were taken from micrographs. Photographs were taken with an automatic Nikon UFX-II 
camera attachment (Nikon Nippon Kogaku K.K.).

\section{Results and Discussion}

All Dracaena species examined possessed cuticular crystals (Table 1). Cuticular deposits in the cultivated group varied among Dracaena species with respect to quantity and size (Fig. 1). Within the dragon tree group characteristics were almost identical with respect to epidermal cell dimensions and crystal deposition (Fig. 1 A, D, and $\mathrm{K}-\mathrm{N}$ ).

Among the cultivated species, $D$. thalioides had the largest cuticular crystals (Fig. 1J). Similarly, D. cincta, D. reflexa and D. sanderiana exhibited fewer, but larger, cuticular deposits (Fig. $1 \mathrm{~B}$ and $\mathrm{G}-\mathrm{H}$ ) in comparison with $D$. arborea, $D$. deremensis, $D$. fragrans, and $D$. surculosa (Fig. 1 A, C, E, and I). Dracaena $\times$ massefiana displayed features of both parents with respect to crystal deposition and epidermal cell characteristics (Fig. 1F). Dracaena sanderiana and D. surculosa contained the fewest crystals per unit cell area (Fig. 1 H-I). Crystal quantity was variable, even in the same species, depending on where the counts were taken. For example, D. sanderiana had large crystals located predominantly along the midline of the epidermal cells. Crystals in $D$. cincta and $D$. thalioides were distributed more uniformly with respect to the epidermal cell area. However, in most species, the largest deposits were located in areas away from the longitudinal cell walls.

In all species, cuticular crystals, especially large ones, as in D. thalioides exhibited high birefringence [a measure of the degree of light refraction as polarized light is passed through a crystal (Klein and Hurlbut, 1993)]. This, together with crystal morphology, indicated that these deposits are probably COM. Their location beneath the cuticle was identical in all species examined and appeared similar to that described in detail for $D$. sanderiana (Pennisi et al., 2001). Dragon tree dracaenas had epidermal cells with length to width ratios of $6: 1$ to $8: 1$. Epidermal cells of $D$. fragrans had the smallest length to width ratio, 1.2:1. Excluding $D$. fragrans, the other species studied possessed epidermal cells with length to width ratios of about $3: 1$ to $15: 1$. The orientation of crystal deposits was random in species that displayed numerous minute cuticular crystals, but less so in species that possessed larger, but fewer crystals. Dracaena fragrans was an exception to these general trends, as it had large but randomly distributed crystals. Crystal orientation was related to epidermal cell shape; the greater the length to width ratio and the larger the deposits, the more regular the orientation of the crystals. This was readily observed in D. fragrans and D. sanderiana, which had crystals comparable in size. The former species had rounded epidermal cells and cuticular crystals were distributed randomly (Fig. 1E). In contrast, the latter species had elongated epidermal cells and the crystals were oriented equidistant from the longitudinal cell walls (Fig. 1H).

No relationship was evident between epidermal cell size and number of crystals. However, dragon tree dracaenas deposited the largest quantity of uniformly small cuticular crystals. The distinction between individual species within this group, based solely on crystal number and size, was not reliable. Crystal deposits in other species of Dracaena had species-specific characteristics. This fact, in combination with leaf epidermal characteristics, could be taxonomically important (see key). The number of culticular crystals remains fixed within a wide range of rhizospheric calcium levels (Pennisi, 1999).

In addition to Dracaena, we examined epidermal peels of Sansevieria and Cordyline. Cells of S. trifasciata (Fig. 1O) and S. cylindrica (not shown) contained numerous minute cuticular crystals, similar in appearance to the crystals exhibited by the dragon tree dracaenas. In contrast, polarized light microscopy revealed no discernible crystalline deposits in C. terminalis (Fig. 1P) or C. australis (not shown). Based on these facts, it is conceivable that Dracaena and Sansevieria share similarities in physiological and anatomical pathways that lead to deposition of calcium oxalate in cuticular leaf areas. Conversely, these same features are not shared among Dracaena-like Cordyline species. In terms of relationships among genera, our findings agree with those of Bogler and Simpson (1996).

Calcium oxalate $(\mathrm{CO})$ crystals occur in more than 200 families of Magnoliophyta Cronquist (syn. Angiospermae A. Braun \& Doell) (Zindler-Frank, 1976) and Pinophyta Cronquist (syn. Gymnospermae Lindley) (Fink, 1991). Angiospermae are characterized by intracellular CO deposition, while a "crystalliferous cuticle" [extracellular crystals embedded in the cuticle, (Oladele, 1982)] is common in coniferous Gymnospermae. In contrast with Gymnospermae, extracellular cuticular CO crystals do not occur commonly in Angiospermae (Franceschi and Horner, 1980). Few detailed studies have investigated the taxonomic value of $\mathrm{CO}$ deposits in a given genus or a family.

Genua and Hillson (1985) surveyed 14 species in Araceae Juss. and recorded the presence of druses, raphides, prismatics, and crystal sand in all species. Chattaway (1955, 1956) provided detailed accounts of crystals in representative species of $\approx 1000$ woody genera of 160 families. She pointed out that some crystal types, such as druses and raphides, and certain crystal arrangements, e.g., large crystals accompanied by smaller ones, might not be common. Chattaway concluded that all these characteristics were valuable features to be included in an identification key to taxa. Recently, Ilarslan and Horner (1999) reported that intracellular CO crystals showed speciesspecific locations, shapes, and numbers within the leaf lamina of representative species of Rosaceae Juss. grown in Turkey. They concluded that the patterns of crystal deposition and characteristics "may be of major significance in sorting out the taxonomy and phylogeny" in Rosaceae.

As noted above, extracellular CO crystals are not a common feature of Magnoliophyta. Few studies have examined cuticular crystal deposits in angiosperm species of the same

Table 1. Comparative analysis of cuticular crystal and epidermal cell characteristics in fourteen Dracaena species.

\begin{tabular}{|c|c|c|c|c|c|c|}
\hline \multirow[b]{2}{*}{ Species } & \multirow[b]{2}{*}{ Cell shape } & \multirow[b]{2}{*}{ Cell L/W ratio z,y } & \multicolumn{4}{|c|}{ Crystal } \\
\hline & & & Quantity ${ }^{\mathrm{y}, \mathrm{x}}$ & Size $^{y}$ & Birefringence & Orientation $^{\mathrm{w}}$ \\
\hline D. arborea & Elongated & $5: 1$ to $7: 1$ & $30-40$ & $0.05-1 \mathrm{~mm}$ & High & Random \\
\hline D. cincta & Elongated & $10: 1$ to $15: 1$ & $5-15$ & $0.05-5 \mathrm{~mm}$ & Very high $^{v}$ & Less random ${ }^{\mathrm{u}}$ \\
\hline D. deremensis & Elongated & $2.7: 1$ to $4.5: 1$ & $20-30$ & $0.05-2 \mathrm{~mm}$ & High & Random \\
\hline D. draco & Elongated & $6: 1$ to $8: 1$ & $50-100$ & $0.05-1 \mathrm{~mm}$ & High & Random \\
\hline D. fragrans & Rounded & $1.2: 1$ to $2: 1$ & $10-20$ & $0.05-3 \mathrm{~mm}$ & $\operatorname{High}^{v}$ & Random \\
\hline D. Xmassefiana & Elongated and rounded & $1.6: 1$ to $6: 1$ & $10-25$ & $0.05-2 \mathrm{~mm}$ & High & Random \\
\hline D. reflexa & Elongated & $5: 1$ to $7: 1$ & $5-20$ & $0.05-7 \mathrm{~mm}$ & High & Less random ${ }^{\mathrm{u}}$ \\
\hline D. sanderiana & Elongated & $10: 1$ to $15: 1$ & $2-5$ & $0.05-6 \mathrm{~mm}$ & Very high ${ }^{v}$ & Less random ${ }^{\mathrm{u}}$ \\
\hline D. surculosa & Elongated & $2.7: 1$ to $5: 1$ & $2-7$ & $0.05-2 \mathrm{~mm}$ & High & Random \\
\hline D. thalioides & Elongated & $5: 1$ to $7: 1$ & $2-10$ & $0.05-12 \mathrm{~mm}$ & Very high ${ }^{v}$ & Less random ${ }^{\mathrm{u}}$ \\
\hline D. cinnabari & Elongated & $6: 1$ to $8: 1$ & $50-100$ & $0.05-1 \mathrm{~mm}$ & High & Random \\
\hline D. ellenbeckiana & Elongated & $6: 1$ to $8: 1$ & $50-100$ & $0.05-1 \mathrm{~mm}$ & High & Random \\
\hline D. ombet & Elongated & $6: 1$ to $8: 1$ & $50-70$ & $0.05-1 \mathrm{~mm}$ & High & Random \\
\hline D. tamaranae & Elongated & $6: 1$ to $8: 1$ & $50-100$ & $0.05-1 \mathrm{~mm}$ & High & Random \\
\hline
\end{tabular}

${ }^{\mathrm{z}}$ Length/width.

${ }^{y} \mathrm{~L} / \mathrm{W}$ ratios, crystal counts, and crystal sizes are averages for 10 cells from each of three leaves from each of three plants.

${ }^{x}$ Per $100 \mu \mathrm{m}^{2}$ of epidermal cell area.

wLong crystal axis with respect to the long cell axis.

${ }^{\mathrm{v}}$ Consistent with calcium oxalate monohydrate (COM).

uSome of the largest crystals parallel to cell axis and equidistant from longitudinal cell walls. 

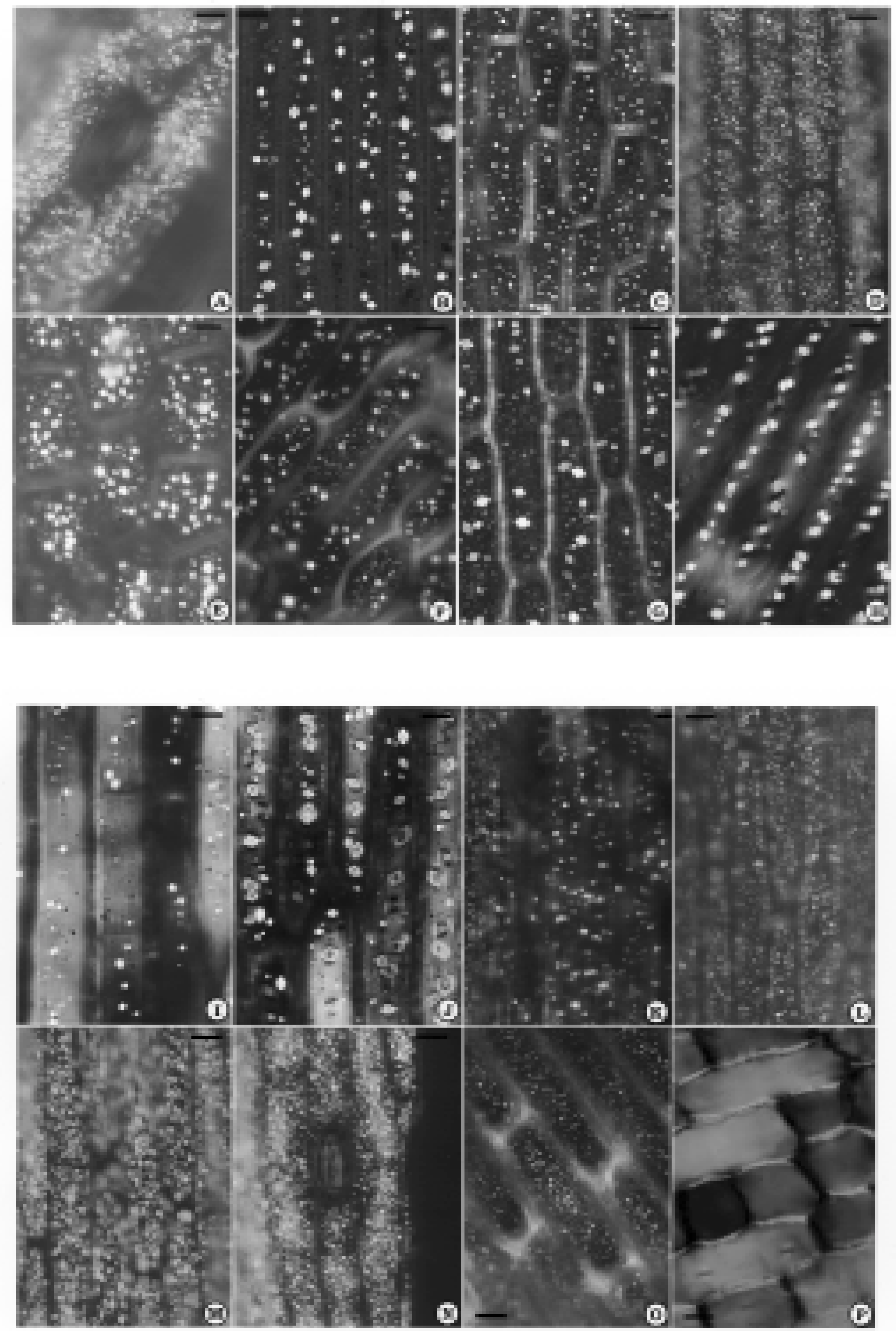

Fig. 1. Light micrographs of epidermal peels of Dracaena and other species, viewed in cross-polarized light to enhance crystal detection. (A) D. arborea. (B) D. cincta. (C) D. deremensis. (D) D. draco. (E) D. fragrans. (F) D. X massefiana. (G) D. reflexa. (H) D. sanderiana. (I) D. surculosa. (J) D. thalioides. (K) D. cinnabari. (L) D. ellenbeckiana. $(\mathbf{M})$ D. ombet. $(\mathbf{N})$ D. tamaranae. $(\mathbf{O})$ Sansevieria trifasciata. $(\mathbf{P})$ Cordyline terminalis. Bars $=10 \mathrm{~mm}$. 
genus or family. Borchert (1984) reported the existence of large numbers of very small, irregular crystals in the epidermal cell walls in honey locust (Gleditsia triacanthos L.). Berg (1994) included a short survey of eight species from three genera of Casuarinaceae $\mathrm{R}$. Br. Although some differences in crystal distribution existed among certain plants, he found $\mathrm{CO}$ crystals embedded in the outer epidermal cell wall in all species. In two genera, the crystal distribution was distinct enough to suggest taxonomic importance for "at least some species."

Ihlenfeldt and Hartmann (1982) described crystalline incrustations in the outer epidermal wall of several species of the water-conserving Mesembryanthemaceae Fenzl. (or Aizoaceae Rud. subfam. Mesembryanthemoideae). The large numbers of $\mathrm{CO}$ crystals illustrated in their drawings were similar to those in the dragon tree group. The presence of crystals in the region between the epidermal cell wall and the cuticle was considered a typical adaptational feature for xerophytic habitats (Ihlendfelt and Hartmann, 1982). Dracaena species exhibited similar adaptations in the structural characteristics of their cuticular layers.

In addition to clearly delineating between Dracaena and Cordyline species, characteristics of the epidermal cells and the cuticular CO crystals allow separation of the Dracaena species we examined except for the dragon tree group.

Key to partial separation of 14 Dracaena species based on cuticular calcium oxalate $(\mathrm{CO})$ crystals and epidermal cell characteristics:

1. Epidermal cells rounded or mix of elongated and rounded epidermal cells-2

1. Epidermal cells predominantly elongated-3

2. Epidermal cells predominantly rounded-D. fragrans

2. Epidermal cells mixed; rounded and elongated-D. Xmassefiana

3. Epidermal cell length/width ratio predominantly $>9: 1-4$

3. Epidermal cell length/width ratio predominantly $<9: 1-5$

4. Number of CO crystals per $100 \mu \mathrm{m}^{2}$ of epidermal cell area 5 or less- $D$. sanderiana.

4. Number of CO crystals per $100 \mu \mathrm{m}^{2}$ of epidermal cell area 5 or more-D. cincta

5. Epidermal cell length/width ratio 5:1 or less-6

5. Epidermal cell length/width ratio 5:1 or greater-7

6. Number of CO crystals per $100 \mu \mathrm{m}^{2}$ of epidermal cell area $<10-D$. surculosa

6. Number of CO crystals per $100 \mu \mathrm{m}^{2}$ of epidermal cell area $>10-D$. deremensis

7. Number of CO crystals per $100 \mu \mathrm{m}^{2}$ of epidermal cell area $<10-D$. thalioides

7. Number of CO crystals per $100 \mu \mathrm{m}^{2}$ of epidermal cell area $>10-8$

8. Number of CO crystals per $100 \mu \mathrm{m}^{2}$ of epidermal cell area $<20-D$. reflexa

8. Number of CO crystals per $100 \mu \mathrm{m}^{2}$ of epidermal cell area $>20-9$

9. Number of CO crystals per $100 \mu \mathrm{m}^{2}$ of epidermal cell area $<50-D$. arborea

9. Number of $\mathrm{CO}$ crystals per $100 \mu \mathrm{m}^{2}$ of epidermal cell area $>50-10$

10. Number of CO crystals per $100 \mu \mathrm{m}^{2}$ of epidermal cell area $<70-D$. ombet

10. Number of CO crystals per $100 \mu \mathrm{m}^{2}$ of epidermal cell area $>70-D$. cinnabari, D. draco, D. ellenbeckia, D. tamarana

\section{Conclusion}

The Dracaena species examined varied in gross morphology, e.g. from trees (D. draco) to shrubs (D. surculosa) and in physiological adaptations, e.g., from full sun (D. draco) to deep shade (D. sanderiana). Detection of cuticular crystals in all species studied indicated that this condition is probably ubiquitous in the genus and may permit rapid separation of dracaenas from plants with similar leaves.

\section{Literature Cited}

Berg, R.H. 1994. A calcium oxalate-secreting tissue in branchlets of the Casuarinaceae. Protoplasma 183:29-36.

Bogler, D.J. and B.B. Simpson. 1996. Phylogeny of Agavaceae based on ITS rDNA sequence variation. Amer. J. Bot. 83(9):1225-1235.

Borchert, R. 1984. Functional anatomy of the calcium-excreting system of Gleditsia triacanthos L. Bot. Gaz. 145(4):474-482.

Fink, S. 1991. Comparative microscopical studies on the patterns of calcium oxalate distribution in the needles of various conifer species. Bot. Acta 104:306-315.
Chattaway, M.M. 1955. Crystals in woody stems. I. Trop. Woods 102:55-70.

Chattaway, M.M. 1956. Crystals in woody stems. II Trop. Woods 104:100-120.

Franceschi V.R. and H.T. Horner Jr. 1980. Calcium oxalate crystals in plants. Bot. Rev. 46:361-427.

Genua, J.M. and C.J. Hillson. 1985. The occurrence, type, and location of calcium oxalate crystals in the leaves of fourteen species of Araceae. Ann. Bot. 56:351-361.

Hutchinson, J. 1959. The families of flowering plants. Vol. 2 ed. 2. Monocotyledonous. Clarendon Press, Oxford.

Hutchinson, J. 1986. Dracaenas in West Africa. Clarendon Press, Oxford.

Ihlenfeldt, H.D. and H.E.K. Hartmann. 1982 Mesembryanthemaceae leaf surfaces. In: D.F. Cutler, K.L. Alvin, and C.E. Price (eds.). The plant cuticle. Academic, London.

Ilarslan, H. and H.T. Horner. 1999. Calcium oxalate crystals in leaves of Rosaceae in Turkey and their importance to taxonomy. (Abstr.).

FASEB Summer Conference on Calcium Oxalate in Biological Systems, Copper Mountain, Colo.

Klein, C. and C.S. Hurlbut, Jr. 1993. Crystallography: External form. Ch. 2. In: Manual of mineralogy. Wiley, New York.

Kohl, F.G. 1889. Anatomisch-physiologische untersuchung der kalksalze und kieselsäure in der pflanze. Elwart'sche verlagsbuchhandlung, Marburg, Germany.

Marrero, A., R.S. Almeida, and M. Gonzalez-Martin. 1998. A new species of the wild dragon tree, Dracaena (Dracaenaceae) from Gran Canaria and its taxonomic and biogeographic implications. Bot. J. Linn. Soc. 128:291-314.

McConnell, D.B., R.W. Henley, and C.B. Kelly. 1989. Commercial foliage plants: Twenty years of change.Proc. Fla. State Hort. Soc. 102:297303.

Oladele, F.A. 1982. Development of crystalliferous cuticle of Chamaecyparis lawsoniana (A. Murr.) Parl. (Cupressaceae). Bot. J. Linn. Soc. 84:273288.

Pennisi, S.V. 1999. Calcium oxalate hydrates in Dracaena sanderiana hort. Sander ex Mast. (Dracaenaceae) and their relevance to the field of biomineralization. PhDDiss., Univ. of Florida.

Pennisi, S.V., D.B. McConnell, L.B. Gower, M.E. Kane, and T. Lucansky. 2001. Periplasmic cuticular calcium oxalate crystal deposition in Dracaena sanderiana. New Phytol. 149:209218.

Takhtajan, A. 1980. Outline of the classification of flowering plants. Bot. Rev. 46:223-359.

Zindler-Frank, E. 1976. Oxalate biosynthesis in relation to photosynthetic pathway and plant productivity-A survey. Z. Pflanzenphysiol. 80(S):1-10. 